\title{
EDITORIAL
}

\section{Respiratory illness in asbestos contaminated sites: the role of environmental exposure}

\author{
P. Comba, L. Fazzo and A. Zona
}

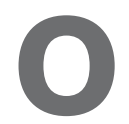
ver the last few years, advances in the assessment of the burden of disease caused by asbestos have taken place, even though the health impact of this agent has been investigated for about a century. The International Agency for Research on Cancer has recently concluded that there is a causal role of asbestos in laryngeal and ovarian cancer, in addition to the previously assessed links with lung cancer and mesothelioma [1]. A European Respiratory Society position paper [2] endorsed the notion of an ongoing mesothelioma epidemic that is expected to peak around 2020 in Western European countries, where asbestos consumption reached its maximum in the mid-1970s and subsequently decreased until its final ban. Currently, Asia and parts of Eastern Europe use $\sim 70 \%$ of the world's production of this mineral, which is also extracted and employed with varying degrees of control and restrictions in Canada, and in parts of Africa and Latin America. Globally, mesothelioma occurrence in the years 1994-2008 was $\sim 174,000$ cases reported in 56 countries and $\sim 40,000$ more cases estimated in countries with the presence of asbestos in the absence of mesothelioma reporting [3].

The health effects of environmental exposure caused by residence in neighbourhoods with asbestos quarries and factories are one of the priority topics for scientific research in this domain. This problem was originally reported by WAGNER et al. [4] in 1960. The issue has since been extensively investigated, bringing to light a range of outcomes and exposure circumstances that have been the subject of a number of evaluations, including the study by STRAIF et al. [1] in 2009 and the Helsinki Conference [5]. Specifically, attention has been paid to tremolite-induced mesothelioma and pleural plaques due to soil contamination in Bulgaria [6], Turkey [7-9], Corsica [10, 11], Greece [12-15], Cyprus [16], New Caledonia [17, 18], Afghanistan [19], Botswana [20] and Italy [21, 22].

The community of Libby (MT, USA) has been the subject of a set of studies concerning the health impact of vermiculite, a silicate used in several industrial applications, mainly as an insulating agent, which was mined and processed from the 1920s until 1990. Libby's vermiculite was contaminated by tremolite and other amphybolic fibres, namely winchite and richterite. Asbestosis and respiratory neoplasms were initially

Dept of Environment and Primary Prevention, Istituto Superiore di Sanità, Rome, Italy.

CORRESPONDENCE: P. Comba, Istituto Superiore di Sanità, Viale Regina Elena 299, Rome, I-00161, Italy. E-mail: pietro.comba@iss.it detected among miners [23, 24], then among millers and processing workers [25]. Subsequently, attention was focused on the health impact for household contacts of workers and for Libby residents. Environmental exposure to Libby amphybolic fibres derives from contact with industrial waste material, and use of vermiculite ore as an insulating agent or as a material for paving paths, gardens and sporting fields [26-28].

In this context, the article by WeILL et al. [29] in this issue of the European Respiratory Journal provides novel scientific insight into lung function and radiological changes associated with different pathways of vermiculite exposure in Libby. In this study, the authors used Agency for Toxic Substances and Disease Registry (ATSDR; Atlanta, GA, USA) data [30] collected in the year 2000 in a survey conducted in 7,307 residents or former residents. The study was restricted to 4,524 subjects aged between 25 and 90 yrs, who were not exposed to asbestos other than in contained vermiculite, with radiological examination and spirometry data available. The authors explored the association between radiological and spirometric findings, smoking habits, and sex, and assessed the effects of exposure reduction due to technological changes that occurred in the processing of vermiculite in the mid-1970s. The main results were an increase in the prevalence of pleural plaques with age, which was lower in subjects with environmental exposure compared with workers, and a significant effect of pleural plaques on forced vital capacity in males. In the general population exposed after 1976, a reduction in the prevalence of pleural plaques, diffuse pleural thickening and costophrenic angle obliteration was documented.

Some comments on open questions appear to be warranted. Given the authors' interest in the possible aetiological role of the environment, allocation of study subjects to exposure categories is of the utmost relevance. This should depend not only on the exclusion of occupational contact with asbestos but also on indicators such as distance of the subject's dwelling from the mine or other major sources of fibres and duration of residence in the area. The available data would allow a focus on the category of environmental exposure.

The international scientific literature, briefly summarised above, consistently indicates that the specific outcomes of environmental tremolite exposure are pleural mesothelioma and pleural plaques. The authors state that: "Mesothelioma mortality was more difficult to assess, due to the inability to have adequate comparison data because of the rarity of this type of cancer". This statement does not seem to be warranted, though, in light of the aforementioned study by SulLIVAN [25] 
showing a standardised mortality ratio calculated for mesothelioma in the occupational cohort and of the report by WHITEHOUSE et al. [27] in 2008 on nine cases of mesothelioma diagnosed in Libby between 1993 and 2006, which were associated with environmental exposure. The county population of $\sim 10,000$ subjects would lead to an expectation of one case in $\sim 10$ yrs. The availability of mesothelioma mortality or incidence figures is essential when estimating health risks in asbestos-contaminated sites, as discussed in a recent Italian study (L. Fazzo, personal communication).

As far as pleural plaques are concerned, their prevalence in some exposure categories, considering post-1976 mitigation conditions, seems to indicate a decrease. It may be worthwhile assessing, over time, whether this reduction will be confirmed, given the latency for the onset of asbestos-related pleural plaques and taking into account all the study subjects.

Commenting on the lung function study of Libby residents is a more complex issue because the available data are spirometric measurements of static and dynamic lung volumes only, and performing carbon monoxide lung diffusion tests is also generally recommended in the case of asbestos-exposed subjects [31]. In any case, WeILL et al. [29] do not find clinically relevant adverse respiratory effects, whereas the ATSDR found moderate-to-severe restriction in breathing capacity in $1.8 \%$ of all those tested [32]. In order to support the absence of a clinically relevant adverse health effect of environmental exposure on lung function, WeILL et al. [29] suggest downgrading the "positive" findings of WHITEHOUSE [33] from 2004, which considered mainly former workers. However, the authors do not comment on the study by VINIKOOR et al. [34] that shows an association between environmental vermiculite exposure and respiratory symptoms, even in the absence of spirometric alterations, in individuals who were children when the mine was active.

In conclusion, the scientific evidence provided by WeILL et al. [29] supports the notion of a reduction in health risks for Libby residents subsequent to 1976 environmental mitigation interventions. However, the available data are not sufficient to rule out adverse respiratory effects of environmental exposure of Libby residents because of limitations in exposure categorisation and the absence of carbon monoxide lung diffusion testing. Pleural mesothelioma monitoring might provide valuable information on post-1976 health risk in the community.

\section{STATEMENT OF INTEREST}

A statement of interest for P. Comba can be found at www.erj. ersjournals.com/site/misc/statements.xhtml

\section{ACKNOWLEDGEMENTS}

The authors wish to thank L. Sampaolo (Istituto Superiore di Sanità, Rome, Italy) for bibliographic search and information retrieval.

\section{REFERENCES}

1 Straif K, Benbrahim-Tallaa L, Baan R, et al. WHO International Agency for Research on Cancer Monograph Working Group. A review of human carcinogens - part C: metals, arsenic, dusts, and fibres. Lancet Oncol 2009; 10: 453-454.
2 Sigsgaard T, Nowak D, Annesi-Maesano I, et al. ERS position paper: work-related respiratory diseases in the EU. Eur Respir J 2010; 35: 234-238.

3 Park EK, Takahashi K, Hoshuyama T, et al. Global magnitude of reported and unreported mesothelioma. Environ Health Perspect 2011; 119: 514-518.

4 Wagner JC, Sleggs CA, Marchand P. Diffuse pleural mesothelioma and asbestos exposure in the North Western Cape province. $\mathrm{Br} \mathrm{J}$ Ind Med 1960; 17: 260-271.

5 Asbestos, asbestosis, and cancer: the Helsinki criteria for diagnosis and attribution. Scand J Work Environ Health 1997; 23: 311-316.

6 Burlikov T, Michailova L. Asbestos content of the soil and endemic pleural asbestosis. Environ Res 1970; 3: 443-451.

7 Yazicioglu S. Pleural calcification associated with exposure to chrysotile asbestos in southeast Turkey. Chest 1976; 70: 43-47.

8 Zeren EH, Gümürdülü D, Roggli VL, et al. Environmental malignant mesothelioma in southern Anatolia: a study of fifty cases. Environ Health Perspect 2000; 108: 1047-1050.

9 Metintas S, Metintas M, Ucgun I, et al. Malignant mesothelioma due to environmental exposure to asbestos. Chest 2002; 122: 22242229.

10 Viallat JR, Boutin C. Radiographic changes in chrysotile mine and mill ex-workers in Corsica. A survey 14 years after cessation of exposure. Lung 1980; 157: 155-163.

11 Viallat JR, Boutin C, Steinbauer J, et al. Pleural effects of environmental asbestos pollution in Corsica. Ann NY Acad Sci 1991; 643: 438-443.

12 Bazas T, Bazas B, Kitas D, et al. Pleural calcification in north-west Greece. Lancet 1981; 2: 254.

13 Constantopoulos SH, Theodoracopoulos P, Dascalopoulos G, et al. Metsovo lung outside Metsovo. Chest 1991; 99: 1158-1161.

14 Sichletidis L, Daskalopoulou E, Chloros D, et al. Pleural plaques in a rural population in central Macedonia, Greece. Med Lav 1992; 83: 259-265.

15 Sichletidis I, Daskalopoulou E, Tsarou V, et al. Five cases of pleural mesothelioma with endemic pleural calcifications in a rural area in Greece. Med Lav 1992; 83: 326-329.

16 McConnochie K, Simonato L, Mavrides P, et al. Mesothelioma in Cyprus: the role of tremolite. Thorax 1987; 42: 342-347.

17 Goldberg P, Goldberg M, Marne MJ, et al. Incidence of pleural mesothelioma in New Caledonia: a 10-year survey (1978-1987). Arch Environ Health 1991; 46: 306-309.

18 Luce D, Bugel I, Goldberg P, et al. Environmental exposure to tremolite and respiratory cancer in New Caledonia: a case-control study. Am J Epidemiol 2000; 151: 259-265.

19 Voisin C, Marin I, Brochard P, et al. Environmental airborne tremolite asbestos pollution and pleural plaques in Afghanistan. Chest 1994; 106: 974-976.

20 Khudu-Petersen K, Bard D, Garrington N, et al. Microscopic identification of asbestos fibres associated with African clay crafts manufacture. Ann Occup Hyg 2000; 44: 137-141.

21 Mirabelli D, Cadum E. [Mortality among patients with pleural and peritoneal tumours in Alta Valle di Susa]. Epidemiol Prev 2002; 26: 284-286.

22 Pasetto R, Bruni B, Bruno C, et al. Pleural mesothelioma and environmental exposure to mineral fibres: the case of a rural area in the Basilicata region, Italy. Ann Ist Super Sanita 2004; 40: 251-265.

23 McDonald JC, McDonald AD, Armstrong B, et al. Cohort study of mortality of vermiculite miners exposed to tremolite. $\mathrm{Br}$ J Ind Med 1986; 43: 436-444.

24 McDonald JC, Harris J, Armstrong B. Mortality in a cohort of vermiculite miners exposed to fibrous amphibole in Libby, Montana. Occup Environ Med 2004; 61: 363-366.

25 Sullivan PA. Vermiculite, respiratory disease, and asbestos exposure in Libby, Montana: update of a cohort mortality study. Environ Health Perspect 2007; 115: 579-585. 
26 Horton K, Kapil V, Larson T, et al. A review of the federal government's health activities in response to asbestos-contaminated ore found in Libby, Montana. Inhal Toxicol 2006; 18: 925-940.

27 Whitehouse AC, Black CB, Heppe MS, et al. Environmental exposure to Libby asbestos and mesotheliomas. Am J Ind Med 2008; 51: 877-880.

28 Adgate JL, Cho SJ, Alexander $\mathrm{BH}$, et al. Modeling community asbestos exposure near a vermiculite processing facility: impact of human activities on cumulative exposure. J Expo Sci Environ Epidemiol 2011; [Epub ahead of print DOI: 10.1038/jes.2011.8].

29 Weill D, Dhillon G, Freyder L, et al. Lung function, radiological changes and exposure: analysis of ATSDR data from Libby, MT, USA. Eur Respir J 2011; 38: 376-383.

30 ATSDR. Asbestos. Libby, Montana. www.atsdr.cdc.gov/asbestos/ sites/libby_montana/ Date last accessed: May 17, 2011. Date last updated: January 20, 2009.
31 British Thoracic Society Standards of Care Committee. BTS statement on malignant mesothelioma in the UK, 2007. Thorax 2007; 62: Suppl. 2, ii1-ii19.

32 ATSDR. Asbestos. Libby, Montana. Medical testing \& results. www.atsdr.cdc.gov/asbestos/sites/libby_montana/medical_testing. html\#Lung Date last accessed: May 17, 2011. Date last updated: January 20, 2009.

33 Whitehouse AC. Asbestos-related pleural disease due to tremolite associated with progressive loss of lung function: serial observations in 123 miners, family members, and residents of Libby, Montana. Am J Ind Med 2004; 46: 219-225.

34 Vinikoor LC, Larson TC, Bateson TF, et al. Exposure to asbestoscontaining vermiculite ore and respiratory symptoms among individuals who were children while the mine was active in Libby, Montana. Environ Health Perspect 2010; 118: 1033-1038. 